\title{
THERMODYNAMIC ANALYSIS OF AUTOTHERMAL REFORMING OF METHANE VIA ENTROPY MAXIMIZATION: HYDROGEN PRODUCTION
}

\author{
T. L. de Souza ${ }^{1}$, C. C. R. S. Rossi ${ }^{2}$, C. G. Alonso ${ }^{3}$, R. Guirardello ${ }^{2}$, V. F. Cabral ${ }^{4}$, \\ N. R. C. Fernandes-Machado ${ }^{1}$, S. Specchia ${ }^{5}$, M. S. Zabaloy ${ }^{6}$, L. Cardozo-Filho ${ }^{1}$ \\ ${ }^{1}$ Universidade Estadual de Maringá, Departamento de Engenharia Química \\ ${ }^{2}$ Universidade Estadual de Campinas, Escola de Engenharia Química \\ ${ }^{3}$ Universidade Federal de Goiás, Instituto de Química \\ ${ }^{4}$ Universidade Estadual de Maringá, Departamento de Engenharia de Alimentos \\ ${ }^{5}$ Politecnico di Torino, Departament of Applied Science and Technology \\ ${ }^{6}$ Universidad Nacional del Sur, Planta Piloto de Ingeniería Química \\ E-mail para contato: tls.engqui@gmail.com (T.L. Souza)
}

\begin{abstract}
In this work a thermodynamic analysis of the autothermal reforming (ATR) of methane was performed. Equilibrium calculations employing entropy maximization were performed in a wide range of oxygen to methane mole ratio $(\mathrm{O} / \mathrm{M})$, steam to methane ratio $(\mathrm{S} / \mathrm{M})$, inlet temperature (IT), and system pressure $(\mathrm{P})$. The main calculated parameters were hydrogen yield, carbon monoxide formation, methane conversion, coke formation, and equilibrium temperature. Further, the optimum operating oxygen to methane feed ratio that maximizes hydrogen production, at $\mathrm{P}=1$ bar, has been calculated. The nonlinear programming problem applied to the simultaneous chemical and phase equilibrium calculation was implemented in $\mathrm{GAMS}^{\circledR}$, using CONOPT2 solver. The maximum amount of hydrogen obtained was in the order of 3 moles of hydrogen per mole of fed methane at $\mathrm{IT}=1000{ }^{\circ} \mathrm{C}, \mathrm{P}=1 \mathrm{bar}, \mathrm{S} / \mathrm{M}=5$, and $\mathrm{O} / \mathrm{M}=0.18$.
\end{abstract}

\section{INTRODUCTION}

Considering the depletion of the fossil reserves, the continuous growth in the global energy demand and the associated environmental impact, nowadays there is a deep need to change the current energy matrix, based primarily on non-renewable fossil fuels, into a clean and sustainable energy matrix based on renewable energy. In this sense there is an increasing interest in the development of alternative renewable energy sources able to fulfill the current energy demand (International Energy Agency, 2012).

Among the alternative sources of energy, hydrogen has a great potential as a new energy carrier. Hydrogen makes possible a more efficient use of energy and has no pollutants emission in its end-use. Furthermore, hydrogen can be obtained either from fossil fuels of from renewable sources. Significant hydrogen-related research and development efforts have been made recently (Petrachi et al., 2005; Specchia et al., 2006; Specchia et al., 2007). 
A promising technology to produce hydrogen is the autothermal reforming (ATR) of methane, which combines the POX and SR processes within the same reactor. ATR can be carried out over a wide range of the $\mathrm{H}_{2} / \mathrm{CO}$ ratio by manipulating the relative inlet concentrations of steam and oxygen (Souza e Schmal, 2005; Santos et al., 2010; Liu et al., 2000; Liu et al., 2002). According to Takeguchi et al. (2003), ATR is an adiabatic, i.e., thermally self-sustaining (Halabi, et al, 2008.; Chang et al., 2010; Hagh, 2004; Rabe et al., 2007, reforming process. In the calculations done in this work, ATR means strict adiabatic condition, which is also identified here as thermoneutral condition.

So far the thermodynamic analysis of ATR reactions has been conducted by Gibbs free energy minimization (GFEm) (Vagia e Lemonidou, 2008; Chen et al., 2010; Li et al., 2008; Wang et al.. 2009). The GFEm method is used to find the thermodynamic equilibrium of a reactive multicomponent system, of given inlet composition, and known pressure and temperature. However an ATR reaction does not evolve under constant temperature and pressure conditions in a continuous adiabatic reactor. In such a reactor, the known information for the outlet stream is the enthalpy rather than the temperature.

Few previous works have reported the use of the entropy maximization method (EMM) (Castier, 2009; Rossi et al., 2011; Freitas e Guirardello, 2012). In the work of Castier (2009) the entropy is maximized but under conditions of constant total internal energy, constant total volume, and constant total amounts of the components for non-reactive systems. In the work of Rossi et al. (2011) the ATR is not considered among the cases studied. Freitas and Guirardello (2012) conducted a thermodynamic analysis of oxidative reforming of methane, using GFEm to determine the equilibrium compositions and EMM just to determine the equilibrium temperatures. However, the entropy maximization method provides complete information on the equilibrium state at known pressure and enthalpy, i.e., it is not limited to the determination of the equilibrium temperature. Otherwise, it also provides the equilibrium composition.

The purpose of this work is to conduct a straightforward thermodynamic analysis of methane ATR, in the context of hydrogen production, employing the EMM at known pressure and enthalpy, to determine the equilibrium compositions and temperatures. The effect of process variables such as pressure, inlet temperature and inlet ratios of reactants, on the equilibrium temperature and composition of the reactive system were investigated over a wide range of conditions.

\section{METHODOLOGY}

The chemical and phase equilibrium of an isobaric and isenthalpic closed (multicomponent) reaction system, with a given inlet composition, may be obtained by the total entropy maximization of the system with respect to $n_{i j}$ and $\mathrm{T}$. The total entropy is given by:

$$
S^{t}=\sum_{i=1}^{N C} \sum_{j=1}^{N P} n_{i j} \cdot \bar{S}_{i j}\left(n_{i j}, T\right)
$$


where $S^{t}$ is the total entropy, $N C$ is the number of components in the system, $N P$ is the number of phases, $n_{i j}$ is the number of moles of component $i$ in phase $j, \bar{S}_{i j}$ is the partial molar entropy of component $i$ in phase $j$, and $T$ is the absolute temperature.

The total entropy is to be maximized subject to the following restrictions:

-Non-negativity of numbers of moles:

$$
n_{i j} \geq 0, i=1, \ldots, N C ; j=1, \ldots, N P
$$

-Conservation of mass, given by the elemental mass balances:

$$
\sum_{i=1}^{N C} \sum_{j=1}^{N P} a_{m i} \cdot n_{i j}=\sum_{i=1}^{N C} a_{m i} \cdot n_{i}^{0}=b_{m}, \quad m=1, \ldots, N E
$$

where $a_{m i}$ is the number of atoms of type $m$ in a molecule of component $i, n_{i}^{0}$ is the inlet total number of moles of component $i, b_{m}$ is the total inlet number of moles of atoms of type $m$, and $N E$ is the number of types of atoms present in the system.

-Enthalpy conservation:

$$
\sum_{i=1}^{N C} \sum_{j=1}^{N P} n_{i j} \cdot \bar{H}_{i j}=\sum_{i=1}^{N C} n_{i}^{0} \cdot \bar{H}_{i}^{0}=H
$$

where $\bar{H}_{i j}$ is the partial molar enthalpy of component $i$ in phase $j, \bar{H}_{i}^{0}$ is the inlet partial molar enthalpy of component $i$, and $H$ is the total inlet enthalpy of the system.

The optimization also requires the satisfaction of the following constraint:

-Non-negativity of the absolute temperature:

$$
T \geq 0
$$

Once the reaction system is at high temperature, the formation of a liquid phase may be disregarded, and the gas phase may be assumed to behave as an ideal gas. In this work, the possible presence in the reactive system of the following components has been considered: methane, carbon monoxide, carbon dioxide, steam, hydrogen, oxygen, nitrogen, and solid carbon. The solid phase has been regarded as composed only of pure graphite (a form of solid carbon).

The simultaneous chemical and phase equilibrium computation by the EMM is a nonlinear programming (NLP) problem. The calculations have been performed using the software GAMS 21.6 (General Algebraic Modeling System), with the CONOPT2 solver option. CONOPT2 uses the Generalized Reduced Gradient approach. A Core i3 (4.00 GB, $2.40 \mathrm{GHz}$ ) computer has been used to perform all simulations. In all cases the computational time was less than $1 \mathrm{~s}$ for a single entropy maximization. 


\section{RESULTS AND DISCUSSIONS}

A thermodynamic analysis based on the entropy maximization was performed to investigate the effects of pressure, inlet temperature, inlet steam-to-methane (S/M) ratio and inlet oxygen-to-methane $(\mathrm{O} / \mathrm{M})$ ratio on the production of hydrogen through methane ATR. The ranges considered for the $\mathrm{O} / \mathrm{M}$ and the $\mathrm{S} / \mathrm{M}$ ratios varied from 0.0 to 0.5 and from 0.25 to 5 , respectively. The range for the inlet temperature was from 400 to $1000{ }^{\circ} \mathrm{C}$, and for the pressure from 1 to 50 bar. This window of conditions was defined in consideration of previous experimental and theoretical works on methane ATR (Halabi et al., 2008; Chang et al., 2010; Akbari et al., 2011; Dias e Assaf, 2004; Santos et al., 2010; Chen et al., 2010; Li et al., 2008; Reese et al., 2010; Simeone et al., 2008; Ayabe et al., 2003; Escritori et al., 2009; Souza et al., 2010; Hoang et al., 2006; Dantas et al., 2010), except for the O/M ratio. A higher $\mathrm{O} / \mathrm{M}$ ratio, in fact, implies a higher equilibrium temperature. The maximum value for the $\mathrm{O} / \mathrm{M}$ ratio is limited by the maximum temperature of applicability of the equations used to calculate the heat capacity $\left(\mathrm{C}_{\mathrm{p}}\right)$ of the components of the reactive system. Thus, $\mathrm{O} / \mathrm{M}$ ratios greater than 0.5 resulted in equilibrium temperatures above such limit, which implies the lack of physical significance for the computed equilibrium.

\subsection{Hydrogen Production}

Figure 1 shows the amount of hydrogen obtained (moles of $\mathrm{H}_{2}$ at equilibrium / moles of $\mathrm{CH}_{4}$ at inlet stream) at various pressures and inlet temperatures as a function of the inlet $\mathrm{O} / \mathrm{M}$ and S/M ratios. It can be seen in Fig. 1 that the amount of produced hydrogen decreases with the increase in pressure. However, at high inlet temperatures and high $\mathrm{O} / \mathrm{M}$ ratios the hydrogen production becomes independent from the pressure, as clearly visible in Figure 1(d). Moreover, higher S/M ratios generally imply higher amounts of hydrogen at equilibrium: steam is a provider of hydrogen atoms. By comparing the graphs in Figure 1, it is clear that generally a higher inlet temperature favors the hydrogen production. A closer look at Figure 1 leads to the conclusion that to increase the hydrogen production it is necessary to adjust properly both the $\mathrm{O} / \mathrm{M}$ ratio and the inlet temperature. For example, it can be observed that the maximum production of hydrogen at $400{ }^{\circ} \mathrm{C}$ inlet temperature and 1 bar pressure [Fig. 1(a)] occurs at the highest $\mathrm{O} / \mathrm{M}$ ratio; whereas at $1000{ }^{\circ} \mathrm{C}$ inlet temperature and 1 bar pressure [Figure 1(d)], the maximum hydrogen production is attained at an $\mathrm{O} / \mathrm{M}$ ratio equal to 0.2 .

\subsection{Carbon Monoxide Formation}

The presence of carbon monoxide in the hydrogen-rich stream to be used in PEMFCs fuel cells is a critical problem. It is well known, in fact, that low-temperature PEMFCs suffer from carbon monoxide poisoning when its concentration exceeds $10 \mathrm{ppm}$ (Liu et al., 2010; Specchia et al., 2011). Therefore, the carbon monoxide concentration is an important parameter to be evaluated in the hydrogen production from reforming reactions when hydrogen is used to feed PEMFCs.

Fig. 2 shows the carbon monoxide mole fraction in the product gas stream as a function of the inlet $\mathrm{O} / \mathrm{M}$ and $\mathrm{S} / \mathrm{M}$ ratios, at varying pressures and inlet temperatures. According to these charts the formation of $\mathrm{CO}$ is strongly influenced by the $\mathrm{O} / \mathrm{M}$ and $\mathrm{S} / \mathrm{M}$ ratios. 

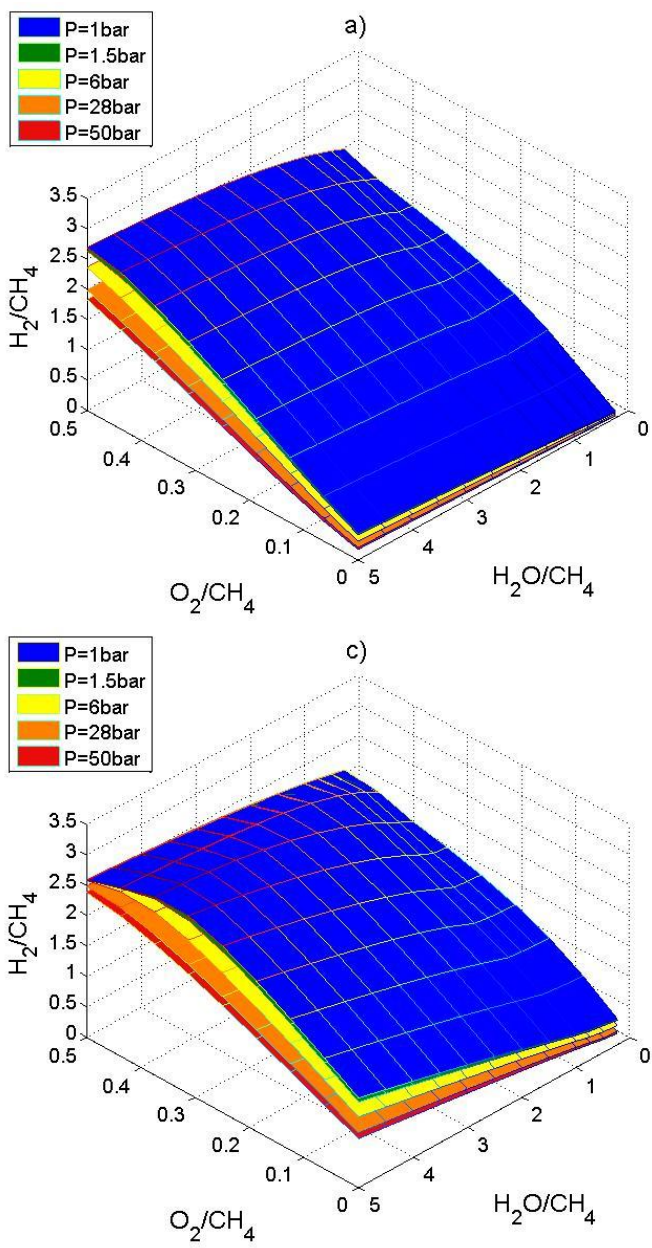

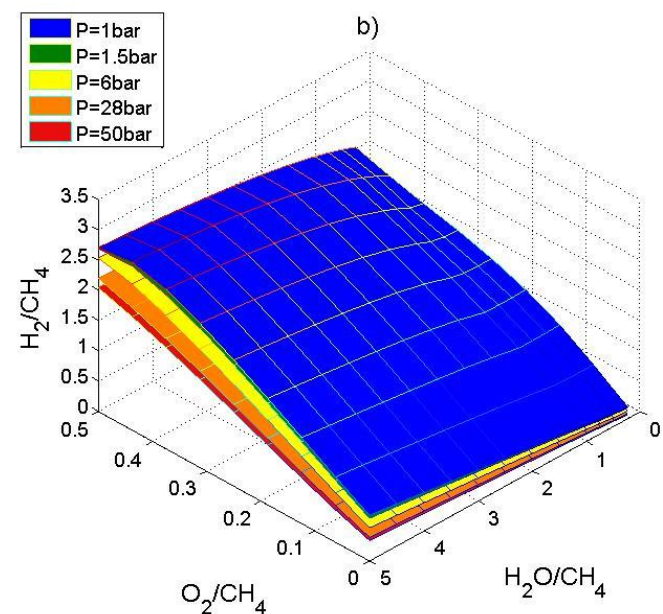

d)

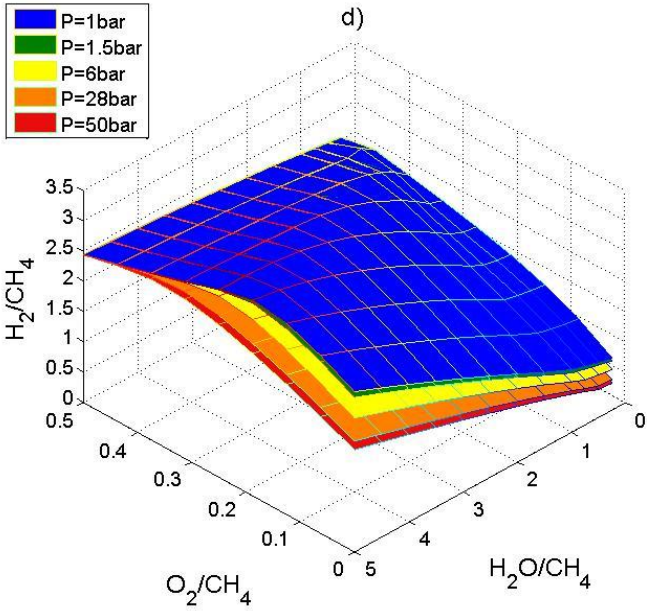

Figure 1 - Number of moles of hydrogen produced per inlet mole of methane as a function of the inlet $\mathrm{S} / \mathrm{M}$ and $\mathrm{O} / \mathrm{M}$ ratios, at several pressure and inlet temperature values: a) $400{ }^{\circ} \mathrm{C}$,

b) $500{ }^{\circ} \mathrm{C}$, c) $700{ }^{\circ} \mathrm{C}$ and d) $1000{ }^{\circ} \mathrm{C}$.

$\mathrm{CO}$ formation does not have a well-defined relation with pressure, as can be seen in Fig 2. Each constant pressure surface profile does not follow exactly the same trend. There are regions where the surfaces overlap, especially at pressures above 28 bar. The way in which the surfaces overlap depends on the inlet temperature. However, the lowest CO mole fraction value, around $16 \mathrm{ppm}$, is found at the highest pressure (50 bar), and inlet temperature $=400$ ${ }^{\circ} \mathrm{C}, \mathrm{S} / \mathrm{M}=5$ and $\mathrm{O} / \mathrm{M}=0$. This lower limit on $\mathrm{CO}$ content is increased as the pressure is decreased: at 1 bar pressure the lowest $\mathrm{CO}$ fraction is around $58 \mathrm{ppm}$ at the same inlet temperature, $\mathrm{S} / \mathrm{M}$ and $\mathrm{O} / \mathrm{M}$ condition. Those conditions do not, however, favor hydrogen production (see Fig. 1) and, if they are anyway imposed, the resulting equilibrium CO content still exceeds the maximum allowed limit for a PEMFCs fuel cell type. Thus, it is necessary to use downstream purification processes to achieve acceptable $\mathrm{CO}$ concentrations in the hydrogen produced from the $\mathrm{CH}_{4}$ ATR if the hydrogen is to be used in a PEMFCs fuel cell type. 
a)

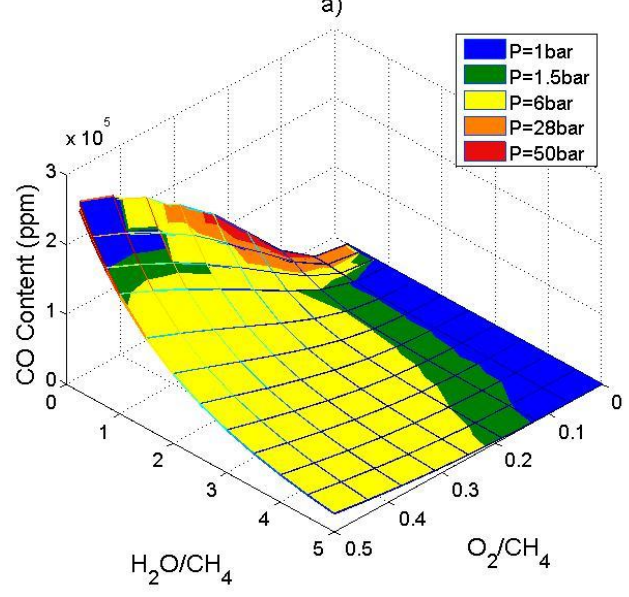

c)

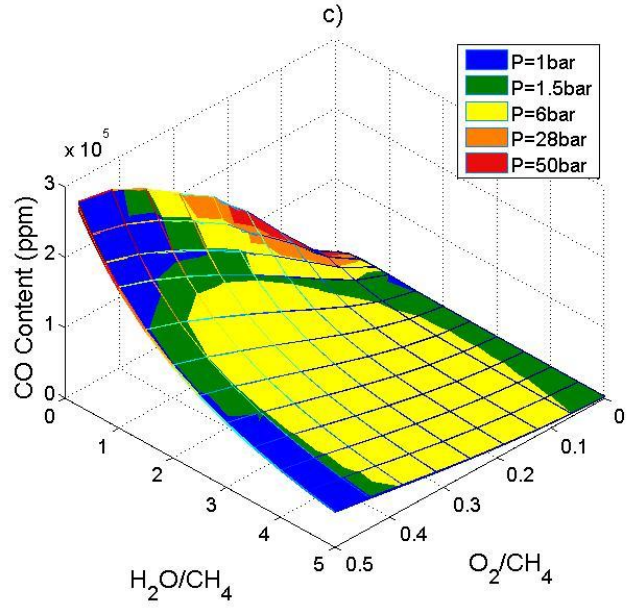

b)

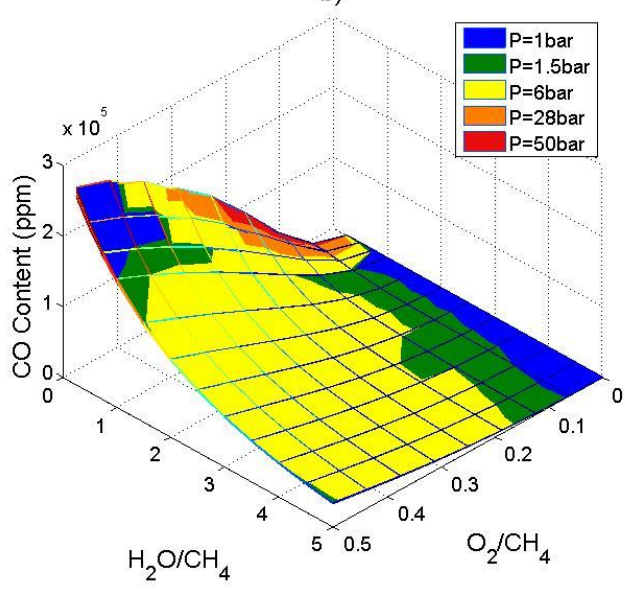

d)

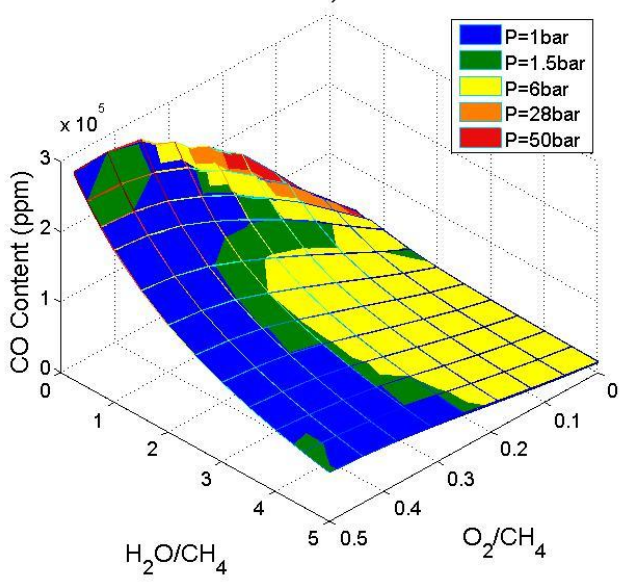

Figure 2 - Mole fraction of $\mathrm{CO}$ at equilibrium as a function of the inlet $\mathrm{S} / \mathrm{M}$ and $\mathrm{O} / \mathrm{M}$ ratios, at several pressure and inlet temperature values: a) $400{ }^{\circ} \mathrm{C}$, b) $500{ }^{\circ} \mathrm{C}$, c) $700{ }^{\circ} \mathrm{C}$ and d) $1000{ }^{\circ} \mathrm{C}$.

\subsection{Coke Formation}

Coke is an undesirable reaction product in catalytic reforming, since the solid carbon can lead to the catalyst deactivation (Souza e Schamal, 2005; Halabi et al., 2008; Escritori et al., 2009; Ruiz et al., 2008; Adhikari et al., 2007).The carbon formation is examined in Fig. 3 which shows the $\mathrm{C} / \mathrm{M}$ ratio (moles of carbon at equilibrium / moles of methane at inlet stream) as a function of the $\mathrm{O} / \mathrm{M}$ and $\mathrm{S} / \mathrm{M}$ ratios, at several inlet temperatures and pressures. According to the graphs shown in this figure, carbon formation is strongly influenced by the $\mathrm{O} / \mathrm{M}$ and $\mathrm{S} / \mathrm{M}$ ratios. It is seen that the increase of these parameters inhibit carbon formation. An increase of the pressure has also an inhibitory effect on the coke formation. In Fig. $3 \mathrm{~d}$ (inlet temperature $=1000{ }^{\circ} \mathrm{C}$ ), in the region defined by an $\mathrm{O} / \mathrm{M}$ ratio between 0 and 0.35 and a $\mathrm{S} / \mathrm{M}$ ratio between 0 and 1.5, the formation of carbon occurs. On the other hand, regardless of the $\mathrm{O} / \mathrm{M}$ ratio, when the $\mathrm{S} / \mathrm{M}$ ratio is higher than 2 carbon formation is inhibited. The same occurs for a $\mathrm{O} / \mathrm{M}$ ratio higher than 0.375 , regardless of the $\mathrm{S} / \mathrm{M}$ ratio. Therefore, coke formation can be easily avoided by properly adjusting the $\mathrm{O} / \mathrm{M}$ and $\mathrm{S} / \mathrm{M}$ inlet ratios. 

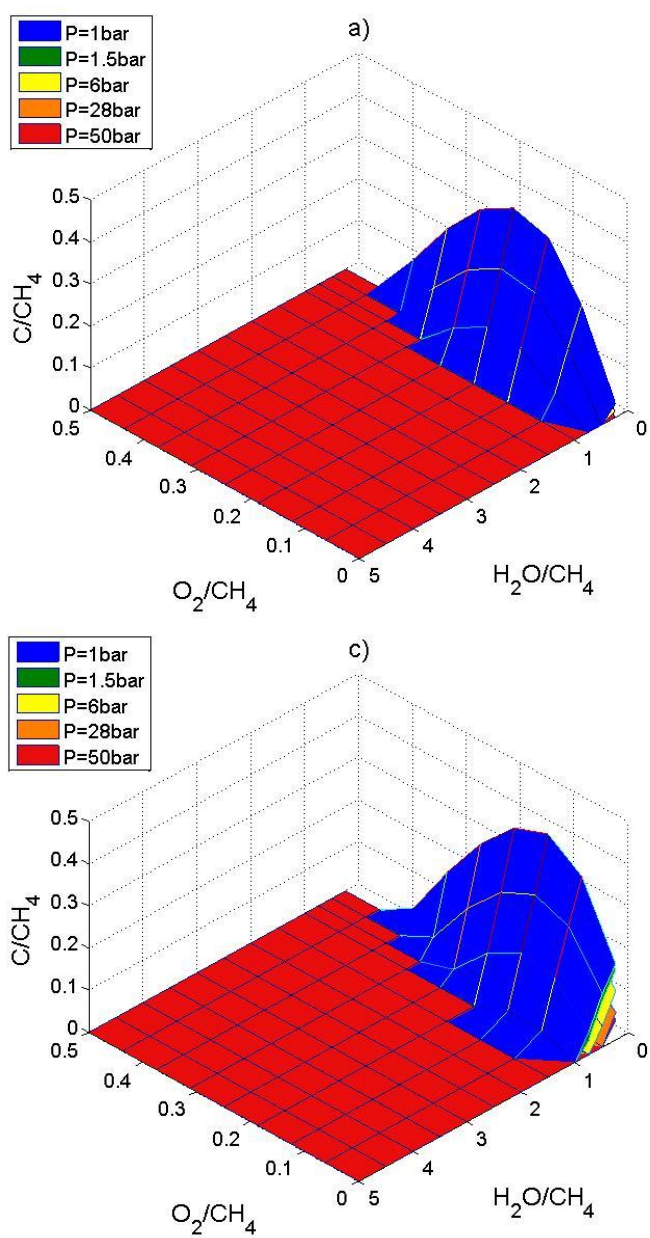

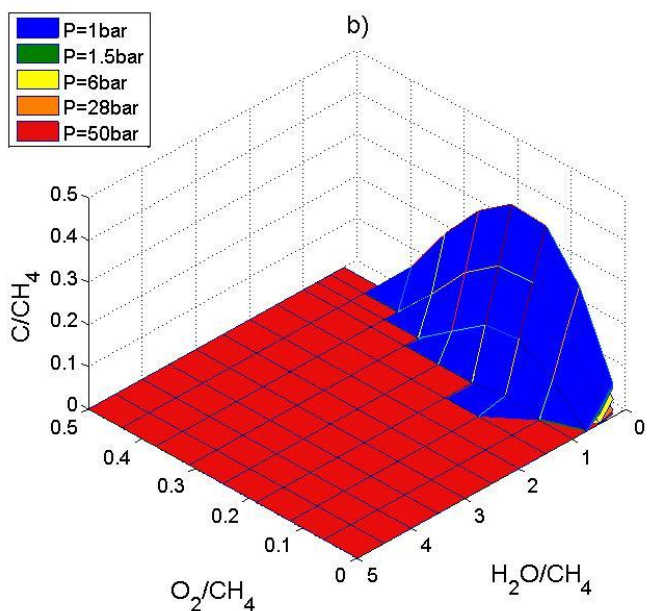

d)

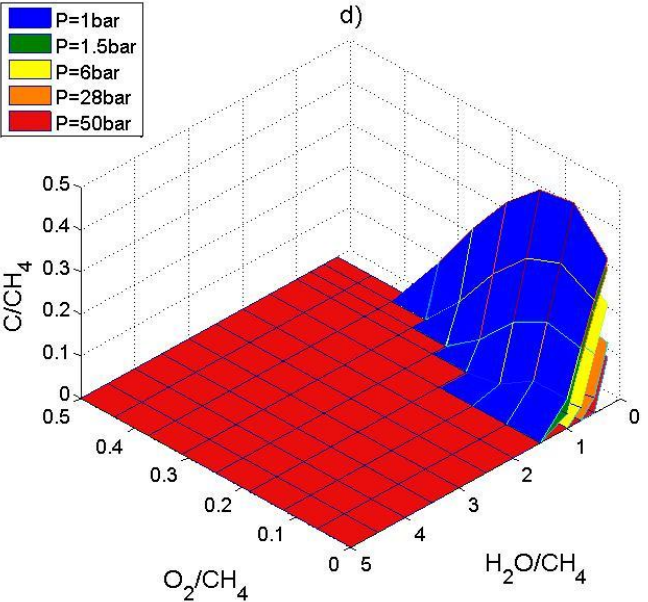

Figure 3 - Number of moles of coke produced per mole of methane as a function of the inlet $\mathrm{S} / \mathrm{M}$ and $\mathrm{O} / \mathrm{M}$ ratios, at several pressure and inlet temperature values: a) $400{ }^{\circ} \mathrm{C}$, b) $500{ }^{\circ} \mathrm{C}$, c) $700{ }^{\circ} \mathrm{C}$ and d) $1000{ }^{\circ} \mathrm{C}$.

\subsection{Methane Conversion} follows:

Methane conversion indicates the process feasibility. This parameter is calculated as

$$
X_{\mathrm{CH}_{4}}(\%)=\frac{n_{\mathrm{CH}_{4}, \mathrm{in}}-n_{\mathrm{CH}_{4}, \mathrm{out}}}{n_{\mathrm{CH}_{4}, \text { in }}} \times 100
$$

Fig. 4 shows the $\mathrm{CH}_{4}$ conversion as a function of the $\mathrm{O} / \mathrm{M}$ and $\mathrm{S} / \mathrm{M}$ ratios for several combinations of inlet temperatures and pressures. First, a pressure increase is unfavorable for enhancing the methane conversion. The lowest pressure value provides, in fact, higher values for the methane conversion. A comparison among the graphs in Fig. 4 shows that an increase of the inlet temperature is extremely favorable to the increase in the conversion. Moreover, the $\mathrm{CH}_{4}$ conversion increases sharply with the increase of the $\mathrm{O} / \mathrm{M}$ ratio, until it reaches a maximum plateau [see Fig. 4 (d)] at around 100\%, and then it remains constant. 

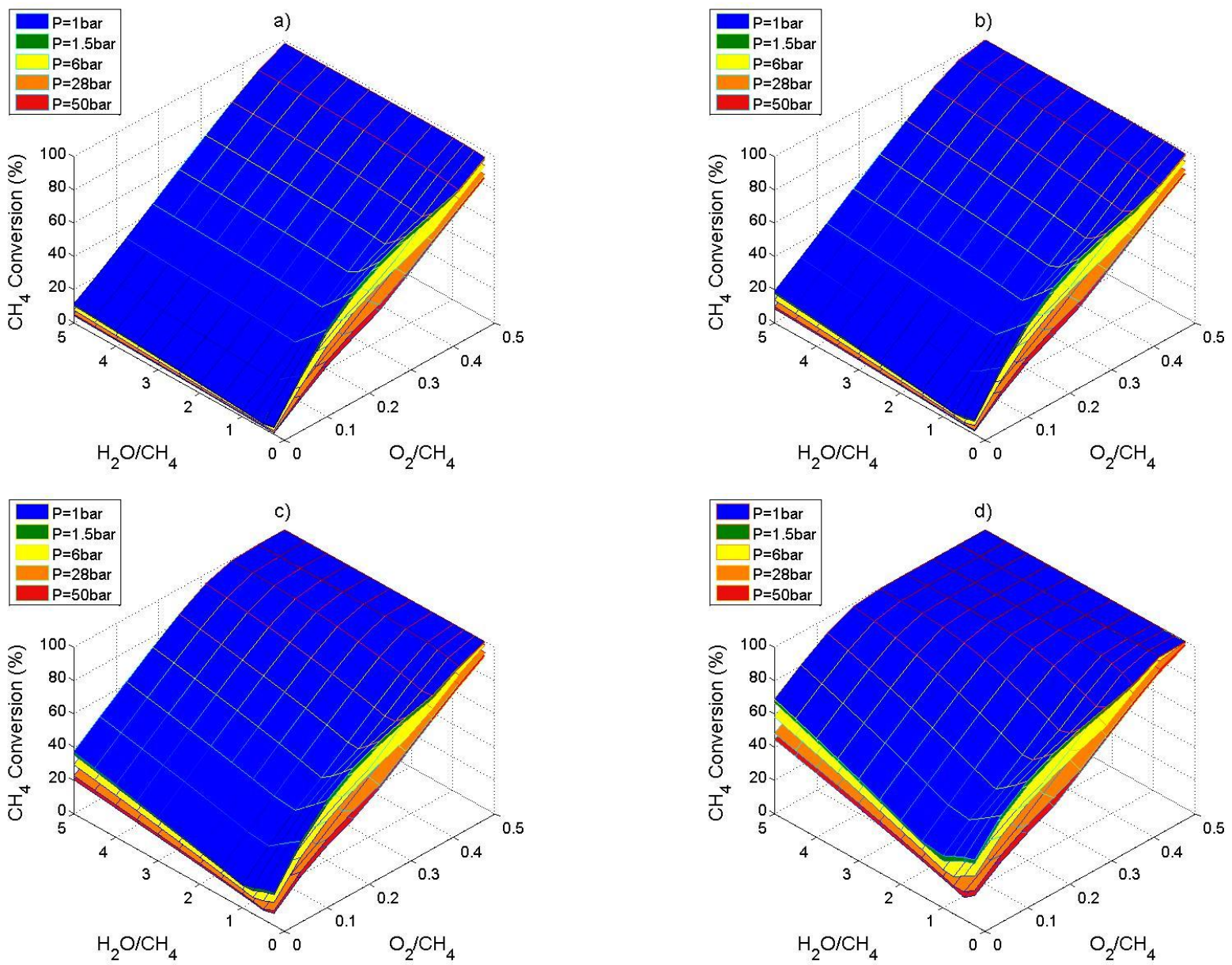

Figure $4-\mathrm{CH}_{4}$ conversion at equilibrium as a function of the inlet $\mathrm{S} / \mathrm{M}$ and $\mathrm{O} / \mathrm{M}$ ratios, at several pressure and inlet temperature values: a) $400{ }^{\circ} \mathrm{C}$, b) $500{ }^{\circ} \mathrm{C}$, c) $700{ }^{\circ} \mathrm{C}$ and d) $1000{ }^{\circ} \mathrm{C}$.

\subsection{Equilibrium Temperature}

ATR process does not occur at constant temperature (Simeone et al., 2008), i.e., the system cannot be considered to be under isothermal conditions; rather, it should be considered adiabatic. Thus, in the ATR process, the system achieves a maximum temperature in the initial reaction stage (oxidation) due to the predominance of exothermic reactions, and then it undergoes a temperature reduction due to the preponderance of endothermic reactions (steam reforming) in the final stage (Simeone et al., 2008; Ruiz et al., 2008). Therefore, the exit stream has different temperature from the maximum one within the reactor. The thermodynamic analysis based on the maximization of entropy enables the direct prediction of the exit stream temperature in the methane reaction conducted under thermoneutral conditions (ATR). Such prediction is based on the assumption that the exit stream is at equilibrium.

Generally, high hydrogen production is favored at low pressure. Thus, the analysis of equilibrium temperature in the methane ATR has been performed only for 1 bar pressure allowing a more detailed analysis. Fig. 5 shows the equilibrium temperature as a function of the inlet $\mathrm{O} / \mathrm{M}$ and $\mathrm{S} / \mathrm{M}$ ratios at different inlet temperatures, by keeping constant the pressure at 1 bar. For a better comprehension of Fig. 5, Fig. 6 has been added to demonstrate the influence of the inlet temperature (IT) and of the $\mathrm{O} / \mathrm{M}$ and $\mathrm{S} / \mathrm{M}$ ratios on the ET/IT 
(equilibrium temperature / inlet temperature) ratio. Fig. 6(a) shows the ET/IT ratio as a function of the $\mathrm{O} / \mathrm{M}$ ratio for different inlet temperatures, at constant $\mathrm{S} / \mathrm{M}$ ratio, i.e., $\mathrm{S} / \mathrm{M}=5$. Fig. 6(b), instead, shows the ET/IT ratio as a function of the S/M ratio for different O/M ratios, at $1000{ }^{\circ} \mathrm{C}$ inlet temperature. From Figures 5 and 6 , the equilibrium temperature is strongly influenced by the $\mathrm{O} / \mathrm{M}$ ratio. The ET/IT ratio increases with the quantity of the fed oxygen [Fig. 6(a)]. Oxygen is the cause of the exothermic reactions. Otherwise, the S/M ratio has little influence on the equilibrium temperature, as clearly visible in Fig.6(b). Although the equilibrium temperature increases with the increase in the inlet temperature [Fig. 5], the ET/IT ratio increases with the decrease in the IT, as shown in Fig. 6(a). The word "isotherm" in figures 6(a) and 6(b) means that the IT equals the ET, and does not necessarily imply a flat temperature profile within the reactor.

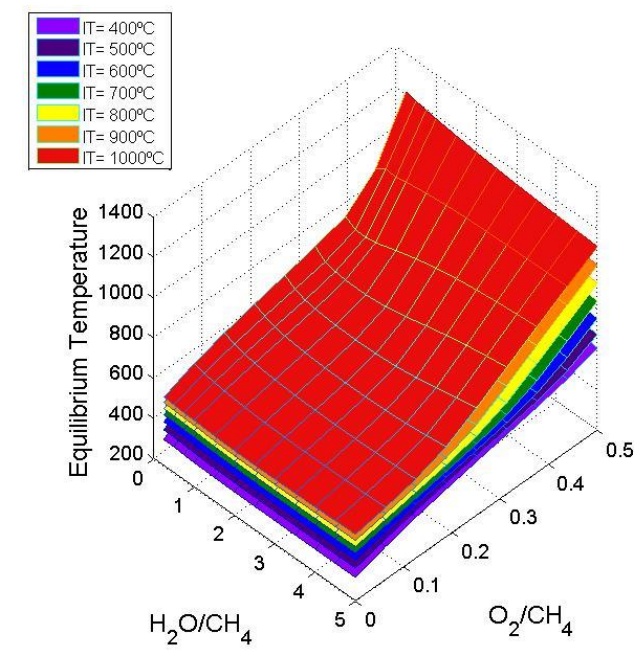

Figure 5 - Equilibrium temperature as a function of the $\mathrm{S} / \mathrm{M}$ and $\mathrm{O} / \mathrm{M}$ ratios, at 1 bar pressure, and at several inlet temperature values.

Fig. 6 shows the regions where there is predominance of the exothermic or of the endothermic reactions. When ET/IT > 1 the exothermic reactions predominate over the endothermic ones, thus there is a net temperature increase for the flowing reactive mixture once it has reached the reactor exit. In this case the endothermic reactions are completely sustained by the exothermic reactions, which provide extra energy that is spent in increasing the temperature of the system, since, because of the adiabatic constraint, no heat can be exchanged with the surroundings. The condition ET/IT $>1$ occurs mainly at high O/M ratio values and low inlet temperatures [Fig. 6(a)]. However, when ET/IT <1 endothermic reactions predominate, thus there is a reduction in the equilibrium temperature of the system, which occurs mainly at high inlet temperatures and low inlet O/M ratios [Fig. 6(a)]. When ET/IT = 1, endothermic and exothermic reactions are energetically balanced, thus the inlet temperature equals the exit (equilibrium) temperature. We have indicated such condition in Fig. 6 through the legend "Isotherm". However we stress that the word "Isotherm" in Fig. 6 does not generally imply a constant temperature along the reactor. 
a)

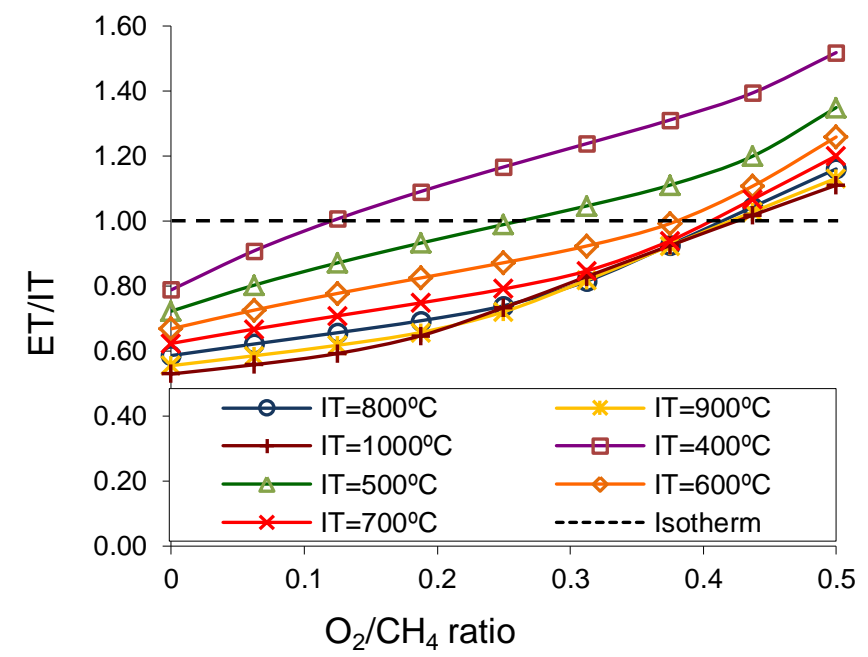

b)

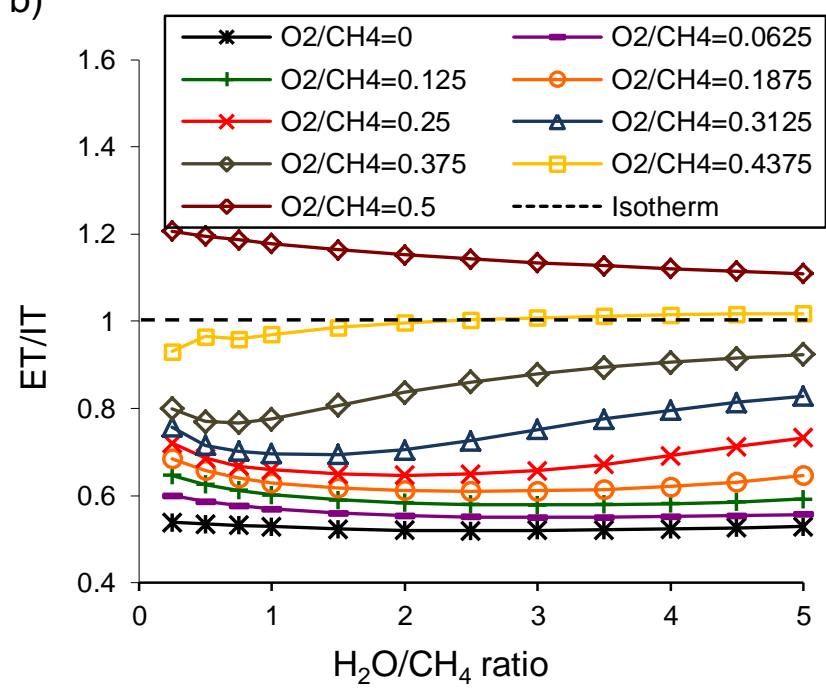

Figure 6 - Equilibrium temperature / inlet temperature ratio (ET/IT) at 1 bar pressure: (a) as a function of the $\mathrm{O} / \mathrm{M}$ ratio, at $\mathrm{S} / \mathrm{M}=5$, and at several inlet temperature values, (b) as a function of the $\mathrm{S} / \mathrm{M}$ ratio, at $\mathrm{IT}=1000{ }^{\circ} \mathrm{C}$, and at several $\mathrm{O} / \mathrm{M}$ ratio values.

\subsection{Optimal Conditions for the Autothermal Production of Hydrogen}

The reactants feed ratios (O/M and S/M), inlet temperature (IT) and system pressure (P) are the operating conditions of the ATR of methane. Therefore, these parameters must be optimized to maximize hydrogen production. However, as it has been shown in section 3.1, the increase of IT, the increase of the S/M ratio and the decrease of $\mathrm{P}$ favor the production of hydrogen. Thus, IT and S/M should be set at their upper bounds and $\mathrm{P}$ at its lower bound. All bounds should account for the operational limits of the reaction equipment. The H/M ratio exhibits a maximum with respect to the O/M ratio. For example, in Fig. 1(d), at $1000{ }^{\circ} \mathrm{C}$ IT , 1 bar pressure, and $\mathrm{S} / \mathrm{M}=5$, the maximum hydrogen production is found at an $\mathrm{O} / \mathrm{M}$ ratio around 0.2 . Thus, the $\mathrm{O} / \mathrm{M}$ ratio is the parameter to be optimized. To obtain the optimal values of $\mathrm{O} / \mathrm{M}$ to maximize the production of $\mathrm{H}_{2}$ it is necessary to fix the values of the remaining parameters (S/M, IT and P). Employing the iterative method of direct search, leaving as free variable the $\mathrm{O} / \mathrm{M}$ ratio and setting the remaining parameters $(\mathrm{S} / \mathrm{M}, \mathrm{IT}$ and $\mathrm{P})$ at their most convenient bounds, the simultaneous chemical and phase equilibrium is calculated for each iteration. The iterative process ends when the variation of the $\mathrm{H} / \mathrm{M}$ ratio in relation of $\mathrm{O} / \mathrm{M}$ ratio is less than $1 \mathrm{E}-8$. Figure 7 (a) shows the optimal values of the $\mathrm{O} / \mathrm{M}$ ratio for maximum hydrogen production as a function of IT for several values of the S/M ratio. Figs. 7(b)-(d), show, respectively, the equilibrium values of the $\mathrm{H} / \mathrm{M}$ ratio, $\mathrm{CO} / \mathrm{M}$ ratio and temperature corresponding to the optimum conditions reported in Fig. 7(a). For all results of this set of optimizations it was observed that the methane conversion lies within a very narrow range, i.e., between 97.3 and $98.4 \%$. For this reason, no chart has been included for the methane conversion as a function of IT and S/M, as it has otherwise been done for other variables in Fig. 7. "Isothermal" points $(\mathrm{ET}=\mathrm{IT})$, indicated in Figure 7 either by "+" symbols [Figs. 7(a) to 7(c)] or by a dashed line [Fig. 7(d)], and by the word "Isotherm" in such figures, were obtained from a linear regression of each constant S/M curve in Fig. 7(d). 

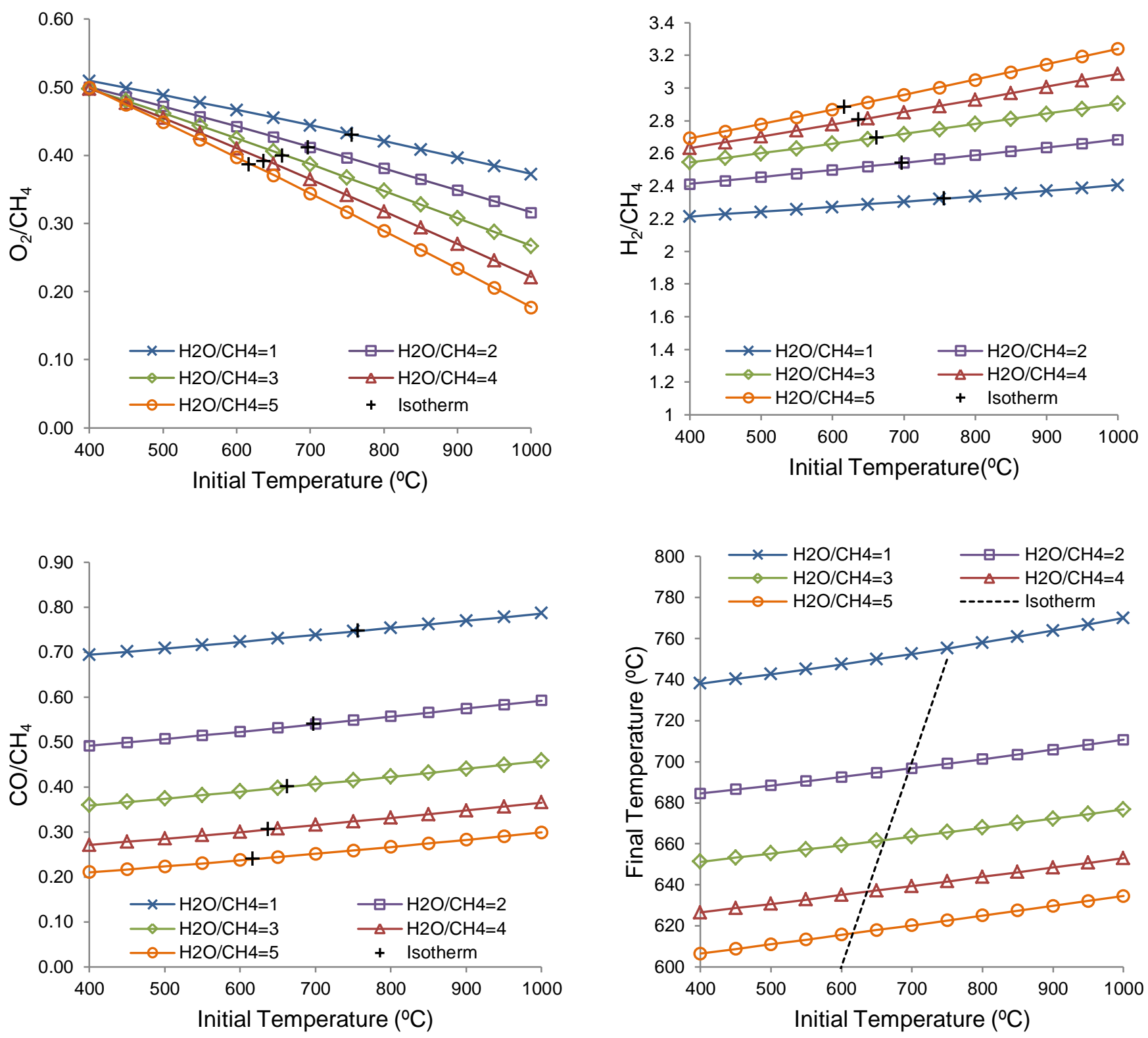

Figure 7 - Optimum O/M ratio operative condition at 1 bar: variables as functions of the inlet temperature, at several S/M ratio values: (a) $\mathrm{O} / \mathrm{M}$ ratio, (b) $\mathrm{H} / \mathrm{M}$ ratio, (c) $\mathrm{CO} / \mathrm{M}$ ratio, and (d) equilibrium temperature. Every point in this figure corresponds to a maximum hydrogen production under equilibrium conditions.

\section{Conclusions}

A thermodynamic analysis of the ATR of methane, carried out through the EMM, has been performed in this work to find conditions that maximize the hydrogen production, over wide ranges of composition, temperature and pressure. The computations considered the chemical and phase equilibrium simultaneously (ideal gas phase, at equilibrium with a pure carbon solid phase). The EMM can directly find the equilibrium corresponding to the 
thermoneutral condition. It does it through a single optimization which simultaneously provides complete information, in particular, the equilibrium composition and temperature. A comparison with literature experimental data, obtained under adiabatic conditions, showed a good agreement with the equilibria calculated at constant pressure and enthalpy.

The main conclusions drawn from the present study are the following:

- Low pressure, high S/M ratios and high inlet temperatures favor the hydrogen production.

-The hydrogen production can be maximized by properly adjusting the $\mathrm{O} / \mathrm{M}$ ratio. The optimum $\mathrm{O} / \mathrm{M}$ ratio decreases with the increase in both, feed temperature and S/M ratio [Fig. 7(a)]. The maximum equilibrium $\mathrm{H}_{2} / \mathrm{M}$ ratio, computed in this work, was in the order of 3.2 [Fig. 7(b)]. This was obtained at 1 bar pressure, $1000{ }^{\circ} \mathrm{C}$ inlet temperature, $\mathrm{S} / \mathrm{M}=5$ [Fig. 7(b)], and optimum O/M in the order of 0.18 [Fig. 7(a)].

- The carbon monoxide formation can be minimized by increasing the S/CH4 ratio and pressure and by reducing the $\mathrm{O} / \mathrm{M}$ ratio and feed temperature. However, these conditions do not favor the production of hydrogen.

- Coke formation can be thermodynamically inhibited by increasing the S/M ratio and/or the $\mathrm{O} / \mathrm{M}$ ratio.

-The equilibrium temperature is mainly affected by the $\mathrm{O} / \mathrm{M}$ ratio whose increase shifts the equilibrium temperature to higher values.

\section{ACKNOWLEDGEMENTS}

We are grateful, for their financial support, to the following institutions: CAPES and CNPq.

\section{REFERENCES}

Adhikari, S.; Fernando, S.; Gwaltney, S. R.; To, S. D. F.; Bricka, R. M.; Steele, P. H. et al. A thermodynamic analysis of hydrogen production by steam reforming of glycerol. Int. $J$. Hydrogen Energ.v. 32, p. 2875-80, 2007.

Akbari, M. H.; Ardakani, A. H. S.; Tadbir, M. A. A microreactor modeling, analysis and optimization for methane autothermal reforming in fuel cell applications. Chem. Eng. J., v. 166, p. 1116-25, 2011.

Ayabe, S. ; Omoto, H.; Utaka, T.; Kikuchi, R.; Sasaki, K.; Teraoka, Y. et al. Catalytic autothermal reforming of methane and propane over supported metal catalysts. Appl. Catal. A: Gen., v. 241, p. 261-9, 2003.

Castier, M. Solution of the isochoric-isoenergetic flash problem by direct entropy maximization. Fluid Phase Equilibr., v. 276, p. 7-17, 2009.

Chang, H. F.; Pai, W. J.; Chen, Y. J.; Lin, W. H. Autothermal reforming of methane for producing high-purity hydrogen in a $\mathrm{Pd} / \mathrm{Ag}$ membrane reactor. Int. J. Hydrogen Energ., v. 35, p. 12986-92, 2010. 
Chen, W. H.; Lin, M. R.; Lu, J. J.; Chao, Y.; Leu, T. S. Thermodynamic analysis of hydrogen production from methane via autothermal reforming and partial oxidation followed by water gas shift reaction. Int. J. Hydrogen Energ., v. 35, p. 11787-97, 2010.

Dantas, S. C.; Escritori, J. C.; Soares, R. R.; Hori, C. E. Effect of different promoters on $\mathrm{Ni} / \mathrm{CeZrO}_{2}$ catalyst for autothermal reforming and partial oxidation of methane. Chem. Eng. J., v. 156, p. 380-7, 2010.

Dias, J. A. C., Assaf, J. M. Autothermal reforming of methane over $\mathrm{Ni} / \gamma-\mathrm{Al}_{2} \mathrm{O}_{3}$ catalysts: the enhancement effect of small quantities of noble metals. J. Power Sources, v. 130, p. 106-10, 2004.

Escritori, J. C.; Dantas, S. C.; Soares, R. R.; Hori, C. E. Methane autothermal reforming nickel-ceria-zirconia based catalysts. Catal. Commun., v. 10, p. 1090-4, 2009.

Freitas, A. C. D.; Guirardello, R. Oxidative reforming of methane for hydrogen and syntesisgás production: Thermodynamic equilibrium analysis. J. Nat. Gas Chem., v. 21, p. 571-80, 2012.

Hagh, B. F. Stoichiometric analysis of autothermal fuel processing. J. Power Sources, v. 130, p. 85-94, 2004.

Halabi, M. H.; Croon, M. H. J. M.; van der Schaaf, J. Modeling and analysis of autothermal reforming of methane to hydrogen in a fixed bed reformer. Chem. Eng. J., v. 137, p. 568-78, 2008.

Hoang, D. L.; Chan, S. H.; Ding, O. L. Hydrogen production for fuel cells by autothermal reforming of methane over sulfide nickel catalyst on a gamma alumina support. $J$. Power Sources, v. 159, p. 1248-57, 2006.

International Energy Agency. World Energy Outlook 2012, London, 2012.

Li, Y.; Wang, Y.; Zhang, X.; Mi, Z. Thermodynamic analysis of autothermal steam and $\mathrm{CO}_{2}$ reforming of methane. Int. J. Hydrogen Energ., v. 33, p. 2507-14, 2008.

Liu, K.; Song. C.; Subramani, V. Hydrogen and Syngas Production and Purification Technologies. New Jersey: John Wiley \& Sons; 2010.

Liu, S.; Xiong, G.; Dong, H.; Yang, W. Effect of carbon dioxide on the reaction performance of partial oxidation of methane over a $\mathrm{LiLaNiO} / \gamma-\mathrm{Al}_{2} \mathrm{O}_{3}$ catalyst. Appl. Catal. A: Gen., v. 202, p. 141-6, 2000.

Liu, Z. W.; Jun, K. W.; Roh, H. S.; Park, S. E. Hydrogen production for fuel cells through methane reforming at low temperatures. J. Power Sources, v. 111, p. 283-7, 2002.

Petrachi, G. A.; Negro, G.; Specchia, S.; Saracco, G.; Maffettone, P. L.; Specchia, V. Combining catalytic combustion and steam reforming in an innovative multifunctional reactor for on-board hydrogen production from middle distillates. Ind. Eng. Chem. Res., v. 44, p. 9422-30, 2005.

Rabe, S.; Truong, T. B.; Vogel, F. Catalytic autothermal reforming of methane: Performance of a kW scale reformer using pure oxygen as oxidant. Appl. Catal. A: Gen., v. 318, p. 54-62, 2007.

Reese, M. A.; Turn, S. Q.; Cui, H. Kinetic modeling of high pressure autothermal reforming. J. Power Sources, v. 195, p. 553-8, 2010. 
Rossi, C. C. R. S.; Berezuk, M. E.; Cardozo-Filho, L.; Guirardello, R. Simultaneous calculation of chemical and phase equilibria using convexity analysis. Comput. Chem. Eng., v. 35, p. 1226-37, 2011.

Ruiz, J. A. C.; Passos, F. B.; Bueno, J. M. C.; Souza-Aguiar, E. F.; Mattos, L. V.; Noronha, F. B. Syngas production by autothermal reforming of methane on supported platinum catalysts. Appl. Catal. A: Gen., v. 334, p. 259-267, 2008.

Santos, D. C. R. M.; Madeira, L.; Passos, F. B. The effect of the addition of $\mathrm{Y}_{2} \mathrm{O}_{3}$ to Ni/ $\alpha-$ $\mathrm{Al}_{2} \mathrm{O}_{3}$ catalysts on the autothermal reforming of methane. Catal. Today, v. 149, p. 4016, 2010.

Simeone, M.; Salemme, L.; Allouis, C. Reactor temperature profile during autothermal methane reforming on $\mathrm{Rh} / \mathrm{Al} 2 \mathrm{O} 3$ catalyst by IR imaging. Int. J. Hydrogen Energ., v. 33, p. $4798-808,2008$.

Souza, A. E. A. M.; Maciel, L. J. L.; Filho, M. L.; Abreu, C. A. M. Catalytic activity evaluation for hydrogen production via autothermal reforming of methane. Catal. Today, v. 149, p. 413-7, 2010.

Souza, M. M. V. M.; Schmal, M. Autothermal reforming of methane over $\mathrm{Pt} / \mathrm{ZrO}_{2} / \mathrm{Al}_{2} \mathrm{O}_{3}$ catalysts. Appl. Catal. A: Gen., v. 281, p. 19-24, 2005.

Specchia, S.; Francia, C.; Spinelli, P. Polymer Electrolyte Membrane Fuel Cells. In: Liu RS, Zhang L, Sun X, Liu H, Zhang J. Electrochemical Technologies for Energy Storage and Conversion, Germany. Weinheim: Wiley-VHC Verlag GmbH \& Co., KGaA; p. 601-70, 2011.

Specchia, S.; Negro, G.; Saracco, G.; Specchia, V. Fuel processor based on syngas production via short-contact-time catalytic-partial-oxidation reactors. Appl. Catal. B: Environ., v. 70, p. 525-31, 2007.

Takeguchi, T.; Furukawa, S. N.; Inoue, M.; Koichi, E. Autothermal reforming of methane over $\mathrm{Ni}$ catalyst supported over $\mathrm{CaO}-\mathrm{CeO}_{2}-\mathrm{ZrO}_{2}$ solid solution. Appl. Catal. A: Gen., v. 240, p. 223-33, 2003.

Vagia, E. C.; Lemonidou, A. A. Thermodynamic analysis of hydrogen production via autothermal steam reforming of selected components of aqueous bio-oil fraction. Int. J. Hydrogen Energ., v. 33, p. 2489-500, 2008.

Wang, H.; Wang, X.; Li, M.; Li, S.; Wang, S.; Ma, X. Thermodynamic analysis of hydrogen production from glycerol autothermal reforming. Int. J. Hydrogen Energ., v. 34, p. 5683-90, 2009. 